\title{
Policy orientation, knowledge dynamic ability and green innovation: A mediation model based on China provincial panel data*
}

\author{
Li Fang $^{1}$, Zhang Sheng ${ }^{2}$
}

\begin{abstract}
Environmental supervision and government subsidy are important tools for government to promote green innovation. The influence of these two policy orientations on green innovation performance is spreading widely, but the specific indirect mechanism of policy orientation inducing green innovation needs further exploring. This paper introduces the knowledge-dynamic ability (knowledge production ability, knowledge acquisition ability, knowledge integration ability) into the analysis framework of enterprise green innovation, and studies the mediating effect of the knowledge-dynamic ability on policy orientation and green innovation. Based on the panel data of 30 provinces in China from 2000 to 2015, the empirical findings are as follows: Firstly, the knowledge-dynamic ability plays a remarkable mediating role in promoting between policy orientation and green innovation, which indicates that improving the knowledge-dynamic ability is a core mechanism of policy orientation to induce enterprise green innovation. Secondly, the knowledge-dynamic ability plays a complete mediating role in the relationship between environmental supervision and green innovation. Environmental supervision promotes green process innovation by enhancing knowledge acquisition ability and induces green product innovation by enhancing knowledge production ability. Thirdly, the knowledge-dynamic ability plays a partial mediating role in the relationship between government subsidy and green innovation. Government subsidy improves enterprise green process innovation by
\end{abstract}

* Received: 18-11-2020; accepted: 15-06-2021

1 Instructor, Nanjing University of Science and Technology, School of Intellectual Property, science technology policy and management, No. 200, Xiaolingwei Street, Nanjing, Jiangsu Province, China, 210094, Scientific affiliation: innovation management, intellectual property right, science technology policy.Phone:+8615829715128.E-mail: 532296776@qq.com.

2 Full professor, Xi'an Jiaotong University, School of Public Policy and Administration, science technology policy and management, NO. 28, Road Xianning West, Beilin District, Xi'an City, Shannxi Province, China, 710049, Scientific affiliation: science technology policy, government governance.Phone: +8602982665254.E-mail:xjtuppasci@163.com.(Corresponding Author). 
enhancing knowledge acquisition ability and knowledge integration ability, and induces enterprise green product innovation by enhancing knowledge production ability and knowledge integration ability.

Key words: policy orientation, knowledge dynamic ability, green innovation, environmental supervision, government subsidy

JEL classification: Q55, Q58, O32, O38

\section{Introduction}

With the increasing environmental pressure of economic development, green innovation has increasingly become the focus of regional development. The green innovation technology market is facing the dual externalities of pollution and technology spillover. It leads to the serious shortage of green innovation performance. The government needs to stimulate enterprises to start with green innovation via policy tools, such as environmental supervision, government subsidy, etc. The existing literature deals in detail with the direct impact of government policy orientation on green innovation but neglects the specific incentive mechanism of these policy orientations on green innovation. Research on the inducing mechanism of policy orientation to green innovations will help to better play the guiding role of policy tools, and promote firm green innovation performance and regional sustainable development.

Existing research lays particular emphasis on the identification of the direct influence of policy orientation on green innovations, and have no unified understanding. Many studies support the induced innovation effect of government policies. An appropriate design of policy tools will stimulate firmsto implement green innovation strategies to strengthen investment in green technology and offset the cost of environmental protection. However, in empirical tests, the influence of policy orientation on green innovation may vary according to different periods, regions and industries, etc. No matter which kind of policy tools impact green innovation, different literature has found different impact relationships, such as promotion, inhibition, inverted U-shaped relationship or uncertainty relationship (Peuckert, 2014; Rexhäuser and Rammer, 2014; Bronzini and Piselli, 2016; Leeuwen and Mohnen, 2017). Guo et al. (2018) also study the impact of two policy orientations concurrently and find environmental supervision policy has a U-shaped impact on green innovation, and government subsidy policy promotes green innovation in China.

But these existing researches focus too much on the empirical test of the direct influence of policy orientation on green innovation and neglected the exploration of the indirect inducing mechanism of policy orientation to green innovation. It is worth noting that the different or even contrary relationships found in relevant studies may also mean that there are still undiscovered indirect inducing 
mechanisms of policy orientation to green innovation. Whether the indirect mechanism works effectively or not has an inherent influence on the action direction of policy orientation to green innovation. Different from these existing researches, this paper focuses on the indirect influence mechanism of policy orientation inducing green innovation, and hopes to identify and explain the induced innovation effect of policy orientation on green innovation more clearly.

While opening the black box of the indirect inducing mechanism, this paper introduces knowledge dynamic ability into the analysis framework of green innovation. Dynamic ability is the enterprises' ability to cope with the dynamism of complex environments and obtain a sustainable advantageous position in the market, which is embodied in the capability of enterprises to discoverand realize opportunities (Teece et al., 1997; Teece, 2010). Zheng et al. (2011) extend the dynamic ability to knowledge management research and put forward the concept of knowledge-dynamic ability. They define it as the capability of enterprises to perceive, produce and integrate knowledge resources in the dynamic environment. Knowledge dynamic ability is the embodiment of enterprise dynamic ability in the field of knowledge and technology innovation.

Under the framework of green innovation, knowledge dynamic ability is more embodied in the ability of enterprises to discover, acquire and apply innovative knowledge. Policy orientation will affect the construction of knowledge dynamic capability of enterprises, and the promotion of knowledge dynamic capability will promote green innovation. Therefore, it is necessary to study knowledge dynamic capability as the core mechanism of policy orientation impact on green innovation. To examine the mechanism, we propose three following research hypotheses:

H1: Policy orientation has a significant positive impact on green innovation.

$\mathrm{H} 2$ : Policy orientation has a significant positive impact on enterprise knowledge dynamic ability.

H3: Knowledge dynamic ability mediates the relationship between environmental supervision and green innovation.

This paper divides green innovation into green process innovation and green product innovation, and studies the mediating effect of the three dynamic abilities of knowledge production ability, knowledge acquisition ability and knowledge integration ability, in the relationship between the two policy orientations of environmental supervision, government funding and green innovation.

Taking the data of 30 provinces in China from 2000 to 2015 as samples, this paper uses step by step test and panel fixed effect regression method and finds that knowledge dynamic ability plays an intermediary role in the relationship between policy orientation and green innovation. 
The innovation of this study is mainly in the following three aspects: First, this paper introduces knowledge dynamic ability and finds that policy orientation can improve an enterprise's green innovation by promoting knowledge- dynamic ability. This indirect incentive mechanism of policy orientation is a powerful supplement to the existing literature focusing on the direct influence mechanism. Second, environmental supervision has a direct- inhibitory effect and an indirect promotion effect on green product innovation through knowledge dynamic ability, which leads to the total effect not significant. This result provides a new explanation for the controversial conclusion in the existing literature. Third, government subsidy has a direct promoting impact on green innovation. It also improves enterprise green innovation by enhancing knowledge dynamic ability.

The main chapters of this paper are arranged as follows: Section 2 reviews the existing research; Section 3 constructs the theoretical model and empirical model; Section 4 presents research data and empirical analysis process; Section 5 provides the results and discussion, and Section 6 reports the findings and conclusion.

\section{Literature review}

Some studies have focused on the effect of the policy orientation on green innovation. However, the existing literature reveals that empirical evidence remains far from the consensus view. There is also some literature focus on the effect of dynamic ability on enterprise innovation. This section reviews the existing literature from three aspects.

\subsection{Policy Orientation and Green Innovation}

The government is committed to resolving the local green innovation market failure by making and implementing an effective environmental supervision policy and government subsidy policy.

Environmental supervision is an important policy tool to control the negative externality of green innovation. Environmental supervision policies set some rules and standards that will limit and guide the direction of green innovations of enterprises. Enterprises choose green innovations to deal with the high standards and strictness of environmental supervision acquiring the leader advantage and innovation benefits in the market. Therefore, well designed and suitable environmental supervision policy will effectively guide firms to engage in technology R\&D and innovation, and partly, sometimes even completely offset the additional regulatory costs (Porter and Linde, 1995). Based on Porter and Linde (1995), Ambec and Barla (2002) further demonstrate the theoretical basis of the hypothesis and find that environmental supervision can reduce agency costs, 
promote enterprises to increase $R \& D$ investment, strengthen pollution-reducing innovation, and improve corporate profits. This hypothesis on the green innovation compensation effect of environmental supervision became the main theoretical basis of the induced innovation effect of environmental supervision policy on green innovation (Hanamoto, 2006). A large number of empirical literature have tested this standpoint. Villegas-Palacio and Coria (2010) study the impact of emission tax and emission permit trading on enterprises' innovation performance and find that although different market incentive policy tools have different impacts on innovation, they all show obvious incentives effect. Based on the statistics and investigation of numerous firms in the EU, Lanoie et al. (2011) conclude that under reasonable environmental regulations enterprise's environmental innovation will be effectively promoted and help to reduce the corresponding production costs. Based on the data of different enterprises in China, Zhao and Sun (2016) and Zhang et al. (2018) find similar conclusions. In addition, Chen et al. (2017) point out that compared with western China, the impact of environmental supervision policy on green innovation is more significant in eastern and central China. Based on regulatory data of seven pilot listed companies, Zhang et al. (2019) study the impact of carbon emissions trading system on green innovation and find that carbon emissions trading mechanism was significantly positively correlated with green innovation.

Some studies have found different conclusions. Environmental supervision may increase enterprises' investment in environmental governance, squeeze out the $\mathrm{R}$ $\&$ D funds in the field of green innovation, and may also strengthen the constraints of production and management, thus limiting the green innovation activities of enterprises. Therefore, under different market structures, environmental regulation tools have differential incentives for green technology R\&D (Montero, 2002). Focusing on German manufacturing enterprises, Wagner (2007) examines the interaction between environmental supervision, environmental innovation and patents, and finds that environmental supervision policy strength has a negative impact the number of patents related to green technological innovation. Chintrakarn (2008) examines the influence of environmental supervision policy on technological efficiency of American manufacturing firms, and finds that environmental regulation has nothing to do with technological efficiency of American manufacturing sector. Perino and Requate (2012) point out that the relationship between environmental supervision policy strictness and the adoption rate of green technology is inverted U-shaped. Guo et al. (2018) use the data of 30 provinces in the period of 20092015 in China and find a U-shaped relationship between environmental supervision policy and green innovation.

Government subsidy is an important policy tool to correct the positive externality of green innovation. Government subsidy will raise the R\&D funds of enterprise green innovation, guarantee enterprises to maintain a high standard of $R \& D$ input, and promote green innovation of enterprises. The "increment" of firm technology 
R\&D investment represents the level of government subsidy guides and generates additional technology R\&D activities (Buisseret et al., 1995). Meanwhile, government subsidies could reduce the risk of enterprises investing in innovation activities, help enterprises invest more funds in new activities, and accelerate the completion of existing projects (Görg and Strobl, 2007). Aiming at the empirical test of the influence of government subsidy on green innovation, David et al. (2000) find that the roles of financial subsidies on various levels of the country, industry and enterprise are different. At the national and industrial levels, government subsidies can promote $\mathrm{R} \& \mathrm{D}$ investment. Based on the perspective of organizational theory, Clarysse et al. (2009) introduce the "learning" process of enterprises in innovation management and explains empirically how the learning process affects the behavior increment of enterprises through the empirical study of IWT plan in Finland. Czarnitzki et al. (2014) have studied the EU Framework Plan, the Cohesive Fund and other government science and technology projects and finds that besides patent quantity, the number of patents cited by subsidized enterprises has also been significantly increased. Guo et al. (2016) use the propensity score matching method and two-stage estimation to study innovation fund of Chinese technology based SMEs and the result shows that technology plan has a major influence on patent quantity and the value of new products of subsidized enterprises. Wang et al. (2017) find that although China's Innovation Fund for technology-based SMEs has improved the survival rate of subsidized enterprises, its effect is not significant on whether the enterprises apply for patents and whether they can get external equity investment.

\subsection{Policy Orientation and Knowledge Dynamic Ability}

The foundations of dynamic ability theory were set by Teece et al. (1997), which propose dynamic ability as the ability of enterprises to integrate, construct and centralize interior and outside resources to gain competitive advantage so as to fit in with dynamic and complex environment. By defining dynamic ability from the perspective of collective behavior patterns, Zollo and Winter (2002) improve the operability and availability of this concept. Teece (2010) define dynamic capabilities as intangible assets that enterprises can create, deploy and protect longterm competitive advantages. Enterprises with strong dynamic capabilities have strong innovative capabilities and entrepreneurship.

Furthermore, for the knowledge dynamic ability, Zheng et al. (2011) elaborate the concept of dynamic ability from the perspective of knowledge base, and propose three kinds of knowledge dynamic abilities. Knowledge production ability refers to the ability of a company to develop and improve actions and processes that contribute to discover and create new knowledge. Knowledge acquisition ability means the ability of enterprises to distinguish and gain useful exterior knowledge. Knowledge integration ability is the ability of enterprises to blend and utilize interior and outside knowledge. Similarly, Monferrer et al. (2015) divide knowledge 
dynamic ability into knowledge adaptability, knowledge absorptivity and knowledge innovation capability. Cheng et al. (2016) divide knowledge dynamic ability into knowledge acquisition and sharing ability.

Aiming at the impact of policy orientation on knowledge dynamic capability, current findings show that policy orientation of government will create an institutional environment, and a good external institutional environment will strengthen the knowledge dynamic ability within enterprises, and a bad one will restrict correspondingly (Delmas, 2002). Based on 200 Spanish enterprise data, Barrales-Molina et al. (2010) study the impact of managers' environmental management concepts on the dynamic capabilities of enterprises and find that managers' environmental awareness has a significant role in promoting dynamic capacity building. Salazar and Peláez (2012) point out that policy orientation related to resource and capacity constraints will affect the dynamic capabilities of technological innovation, and the establishment of information technology innovation centers will help promote the organic growth of the dynamic capabilities of innovation. Using cross-sectional industry data of 188 Russian SMEs, Volchek et al. (2013) study the relationship between policy orientation, innovation capability and internationalization of enterprises, and find that external policy orientation will affect the dynamic innovation capability of enterprises.

Specifically, new environmental rules and standards require enterprises to understand and master the new knowledge of relevant technology and management and guide and promote the improvement of enterprise knowledge dynamic ability. Based on a resource-based view, government subsidy strengthens enterprise innovation resources and urges enterprises to transform innovation resources into knowledge dynamic ability, and then improves knowledge dynamic ability of enterprises (King and Tucci, 2002). Russo (2010) studies the impact of the implementation of the ISO14001 environmental management standard on the improvement of the enterprise production process and finds that the new environmental management standard promotes the knowledge dynamic ability of the enterprise. Based on the survey data of the Emilia-Romagna region in Italy, Antonioli et al. (2014) find a similar conclusion for government fund policy.

\subsection{The Mediating Role of Knowledge Dynamic Ability}

Existing literature has recognized the important part of dynamic ability played in promoting green innovation and started exploring the mediating role of dynamic ability.

Dynamic ability ensures the advantages of enterprises in the complex competitive environment, enables enterprises to identify and seize the opportunities of green innovation, allocates resources to carry out innovation activities, realizes green innovation, and improves the green innovation ability and performance of 
enterprises (Ellonen et al., 2009; Chen and Chang, 2013; Weerawardena et al., 2015). Focus on Taiwanese lighting manufacturers, Wu et al. (2016) put forward that dynamic organizational capability will reduce the impact of environmental changes on enterprises, increase the perception and integration ability of enterprises' green innovation opportunities, and advance enterprises' green innovation.

Policy environment, industrial market, organization, managers and other factors will affect the dynamic ability and enterprise performance (Deeds et al., 2000), dynamic ability play an important intermediary role between these factors and enterprise performance. Based on the data of Italian manufacturing enterprises, Dangelico et al. (2017) find that the sustainable dynamic capabilities such as resource integration and re-allocation are significantly correlated with the green product design capability, and only the external resource integration capability is positively and significantly correlated with the green product innovation capability. Combining sustainable supply chain management with dynamic theory, Hong et al. (2018) test the mediating effect of dynamic capability of supply chain between supply chain management practice and firm performance.

To summarize, the direct impact of policy orientation on green innovation has been widely discussed and the mediating role of dynamic ability has been concerned by the existing literature. However, the indirect impact of policy orientation on green innovation and the role of knowledge dynamic ability have been ignored by existing literature. Therefore, this paper aims to contribute to the literature by introducing knowledge dynamic ability into the research of the relationship between policy orientation and green innovation. This paper tries to demonstrate the mediating role of knowledge dynamic ability on policy orientation and green innovation, and to clarify the inducing mechanism of policy guidance for green innovation.

\section{Methodology}

In this section, the theoretical model and empirical model are constructed. Based on reviewing existing research, a theoretical model of the mediating effect of knowledge dynamic ability on policy orientation and green innovation is establishedTo validate the theoretical model and related hypotheses constructed in this paper, an econometric model is established by step by step test and panel fixed effect regression method. In addition, variable design and data collection are presented in this section.

\subsection{Theoretical model}

By introducing knowledge dynamic ability into the relationship between policy orientation and green innovation, the mechanism of policy orientation inducing 
green innovation is studied. Based on the above research concerning the correlation between policy orientation, knowledge dynamic ability, and green innovation, a theoretical model of the mediating effect of knowledge dynamic ability on policy orientation and green innovation is established, as shown in Figure 1.

Figure 1: Mediating Model of Knowledge Dynamic Ability in the Relationship between Policy Orientation and Green Innovation

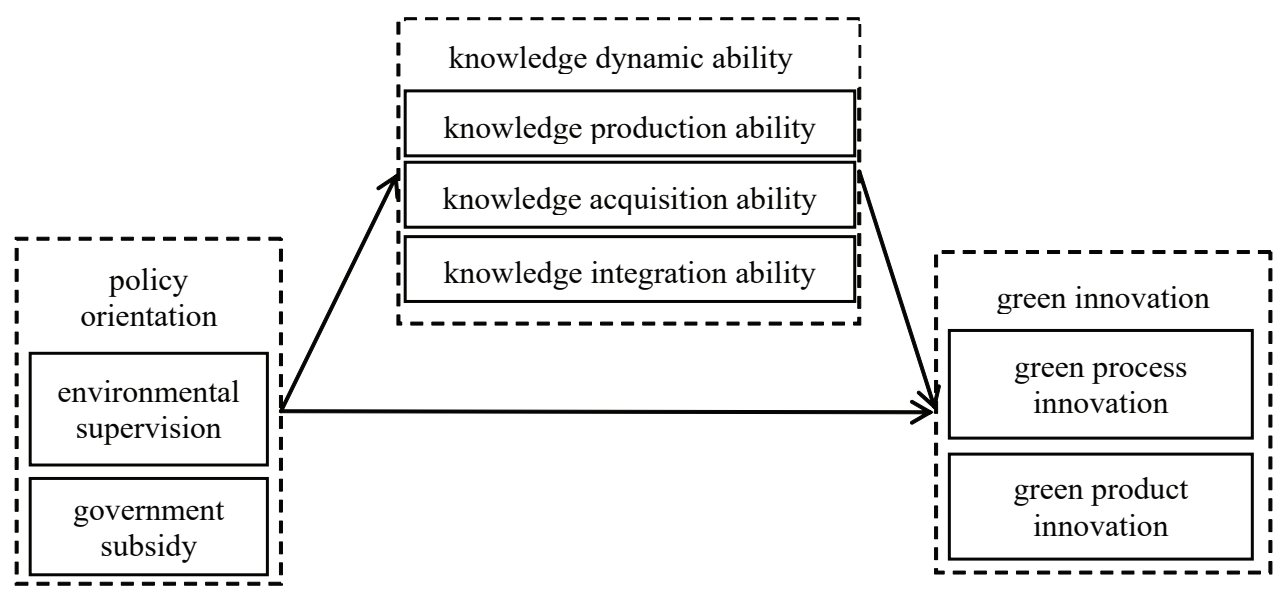

Source: Authors' concept

According to the model, government policy orientation includes environmental supervision and government subsidy. Knowledge dynamic ability includes knowledge production ability, knowledge acquisition ability, and knowledge integration ability. Green innovation includes green process innovation and green product innovation. Policy orientation will promote green innovation. Knowledge dynamic ability has a mediating effect between them, that is, policy orientation promotes green technological innovation by promoting enterprise knowledge dynamic ability.

\subsection{Empirical model}

In order to validate the theoretical model and related hypotheses constructed above, an econometric model is established to empirically test the mediation effect.

Step-by-step method put forward by Baron and Kenny (1986) is the most popular method to verify the mediation effect. Firstly, it measures the effect of the independent variable on dependent variable and observes the significance of the regression results; secondly, it measures the influence of independent variable on the mediating variable and observes the significance of the results; thirdly, it 
measures the influence of both independent variable and mediating variable on the dependent variable, and observes whether both variables, the independent and mediating are significant. If the test results are significant, it implies the significant part of the mediation effect; if in the third step test, theindependent variables are not significant, but all the others are, then it shows, that there is a complete mediation effect.

This sequential test is more effective than other methods, although it has lower test power. Therefore, this paper examines the mediating role of knowledge dynamic ability by step-by-step method.

The panel data regression method was used for empirical test. In order to decrease the heteroscedasticity of the regression and the multi-collinearity between variables, most variables are logarithmically entered into the model. The empirical model to test the mediation effect is as follows:

$Y_{i t}=\alpha_{0}+\alpha_{1}$ Env $_{i t}+\alpha_{2}$ Gov $_{i t}+$ Control $_{i t}+\varepsilon_{i t}$

Find $_{i t}=\beta_{0}+\beta_{1}$ Env $_{i t}+\beta_{2}$ Gov $_{i t}+$ Control $_{i t}+\varepsilon_{i t}$

$A c q u_{i t}=\beta_{0}+\beta_{1}^{\prime} E n v_{i t}+\beta_{2}^{\prime}$ Gov $_{i t}+$ Control $_{i t}+\varepsilon_{i t}$

$\operatorname{Comb}_{i t}=\beta_{0}+\beta_{1}^{\prime \prime} \operatorname{Env}_{i t}+\beta_{2}^{\prime \prime}$ Gov $_{i t}+$ Control $_{i t}+\varepsilon_{i t}$

$Y_{i t}=\alpha_{0}+\alpha_{1}^{\prime} \operatorname{Env}_{i t}+\alpha_{2}^{\prime} \operatorname{Gov}_{i t}+\gamma_{1} \operatorname{Prod}_{i t}+\gamma_{2}$ Acqu $_{i t}+\gamma_{3}$ Inte $_{i t}+$ Control $_{i t}+\varepsilon_{i t}$

In the above model, $i$ represents regions and $t$ represents years. $Y_{i t}$ represents the green innovation level of region $i$ in $t$ year, including green process innovation Process $_{i t}$ and green product innovation Product $t_{i t}$.

Model (1) examines the impact of policy orientation on green innovation, model (2) - (4) examines the impact of policy orientation on knowledge dynamic ability, and model (5) examines the impact of policy orientation and knowledge dynamic ability on green innovation.

\subsection{Variable design}

\subsubsection{Dependent Variables}

Green innovation means that enterprises can save resources and reduce emissions by researching and developing processes, technologies and products that meet the requirements of environmental protection (Wong, 2013). In empirical research, green innovation is generally measured from two dimensions: process innovation and product innovation. 
Green process innovation focuses on technological optimization and equipment improvement in production process (Lin et al., 2014). As for the measurement of green process innovation, existing studies usually choose technical transformation investment or pollution intensity of unit output value to indicate enterprise innovation activities in production process (Xie et al., 2016; Feng and Chen, 2018; Guo et al., 2018). Draw on the experience of Feng and Chen (2018), the level of green process innovation is measured by enterprise technology transformation fund. The more funds enterprise invested in technological renovation, the higher the degree of green process innovation.

Green product innovation focuses on technological innovation investment and activities in product development process (Wong, 2012). As for the measurement of green product innovation, existing studies usually choose share of sales of newly created green product, new product income unit energy consumption, eco-labeling product certification to indicate enterprise in product development process (Chen et al., 2006; Stucki et al., 2018; Feng and Chen, 2018; Guo et al., 2018). Refer to this train of thought, green product innovation is measured in terms of enterprise new product development fund. The more funds enterprise invested in new product development, the higher the degree of green product innovation.

\subsubsection{Independent Variables}

Because of the particularity of green innovation, there are two main aspects of the government policy orientation: environmental supervision and government subsidy.

As for the measurement of environmental supervision, most of the existing studies choose industrial pollution control investment, operation cost of pollution control facilities, sewage discharge fee and other indicators to indicate the cost of pollution treatment of enterprises (Lanoie et al. 2008; Walker, 2011; Rubashkina et al., 2015). On the basis of this line of thought, the degree of environmental supervision is measured by the ratio of industrial pollution treatment investment to industrial main business income. The greater the investment in environmental treatment of unit business income, the higher the degree of local environmental supervision.

Government subsidy represents the degree of local government financial input for enterprises' scientific and technological activities (Zhu et al., 2006; Czarnitzki and Lopesbento, 2014). Industrial firms are the principal part of green technology innovation in a region. On the basis of Guo et al. (2018), the level of government subsidy is measured by the part of funds for scientific and technological activities of industrial firms comes from government funding. 


\subsubsection{Mediator variables}

Knowledge dynamic capability refers to the knowledge production capacity, knowledge acquisition ability and knowledge integration ability of enterprises during the green innovation course, focusing on discovering technological opportunities, acquiring technological opportunities, realizing technological innovation respectively. According to the definition, the three dimensions of knowledge dynamic ability is measured.

Enterprises mainly discover opportunities for technological innovation by carrying out knowledge R\&D activities (Chaminade and Vang, 2008). This paper measures knowledge production ability based on internal R\&D expenditure. By means of internal $R \& D$, enterprises acquire technology by introducing external innovations (Cassiman and Veugelers, 2006). Therefore, knowledge acquisition ability is measured by the sum of technology funds introduced by enterprises and domestic technology funds purchased. After introducing technology, enterprises realize the integration and application of technology by digesting and absorbing technology knowledge (Boer et al., 1999). Therefore, the ability of knowledge integration is measured by digesting and absorbing technology funds.

\subsubsection{Control Variables}

The effect of policy orientation on green innovation is influenced by regional, industrial and resource endowments. In order to control the influence of these factors, local economy, industrial structure, technological market development and local openness are selected as control factors. Local economy is measured by GDP per capita, the industrial structure is measured by the ratio of the secondary industry added value to GDP, the level of technological market development is measured by the amount of technology market contract transactions in that year, and the degree of local openness is measured by foreign investment in the region.

\subsection{Data collection}

Because of the availability and stability of data, we have selected China's provincial data as samples for empirical testing. The policy orientations such as environmental supervision and government subsidies have obvious regional heterogeneity on green innovation. The use of provincial statistics can effectively control the heterogeneity caused by regional differences. According to the statistical data, the measurement data of knowledge dynamic ability of enterprises and the measurement data of green innovation are from 2000 to 2015 . The research interval of sample selection is 2000-2015, and the relatively long-time interval of sample data can obtain more stable and reliable analysis results. The panel data of 480 samples from 30 provinces in 2000-2015 were obtained after eliminating the missing provinces. 
Li Fang, Zhang Sheng $\bullet$ Policy orientation, knowledge dynamic ability and green...

The main data sources include: Statistical Yearbook of Scientific and Technological Activities of Industrial Enterprises, China Scientific and Technological Statistical Yearbook, China Environmental Statistical Yearbook and China Statistical Yearbook.

\section{Empirical data and analysis}

This section shows the results of empirical analysis, including descriptive statistics of sample data, correlation coefficient test and panel data regression model.

\subsection{Descriptive statistics of sample data}

Firstly, descriptive statistical analysis of sample data, including sample number, average, standard deviation, maximum and minimum, is presented in Table 1. In order to reduce heteroscedasticity as much as possible, logarithmic data of variables such as green process innovation, green product innovation, government $R \& D$ funding, knowledge dynamic ability and per capita GDP are taken.

Table 1: Descriptive statistical analysis of sample data

\begin{tabular}{|l|c|c|c|c|c|}
\hline \multicolumn{1}{|c|}{ Variable } & Sample Size & Average & Standard Deviation & Minimum & Maximum \\
\hline Process & 480 & 13.27639 & 1.340362 & 6.813445 & 15.78666 \\
\hline Product & 480 & 12.82482 & 1.781359 & 7.302496 & 16.72298 \\
\hline Env & 480 & 0.008357 & 0.0342817 & 0.000563 & 0.613932 \\
\hline Gov & 480 & 10.32511 & 1.577602 & 2.70805 & 13.10724 \\
\hline Prod & 480 & 12.81263 & 1.708944 & 7.212295 & 16.53717 \\
\hline Acqu & 480 & 11.25991 & 1.527597 & 4.543295 & 14.06392 \\
\hline Inte & 480 & 9.165372 & 2.062116 & 0 & 12.56639 \\
\hline pGDP & 480 & 9.932681 & 0.811097 & 7.922624 & 11.58952 \\
\hline Indu & 480 & 46.12949 & 7.754637 & 0.1329 & 19.760 \\
\hline Mar & 480 & 12.49155 & 1.760505 & 6.395262 & 17.3576 \\
\hline Open & 480 & 4.636202 & 6.299516 & 0.01283 & 35.75956 \\
\hline
\end{tabular}

Source: Authors' calculation

\subsection{Statistical test}

Using Pearson correlation coefficient to test the correlation between variables, the specific coefficients are shown in Table 2. From Table 2, we can see that there are significant correlations among variables.

After correlation coefficient test, variance expansion factor test is used. The average variance expansion factor of the model is 4.93 , which indicates that does not exist multiple-collinearity among the variables. 


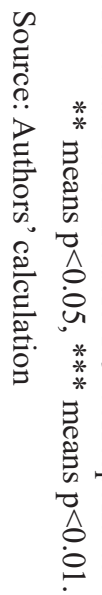

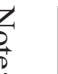

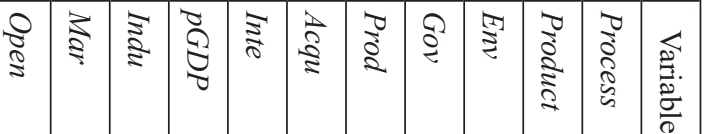

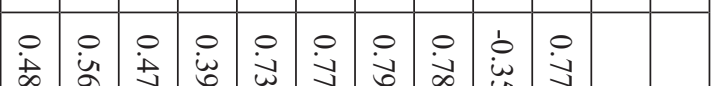

弯

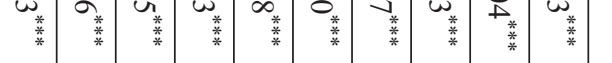

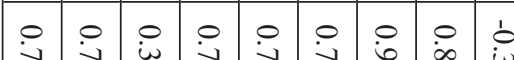

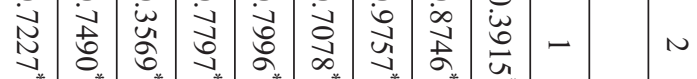

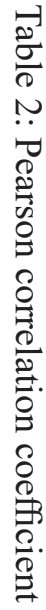

泀

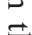

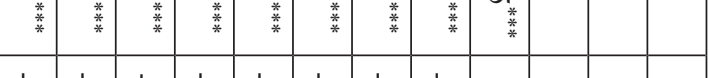

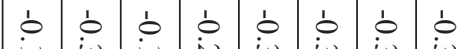

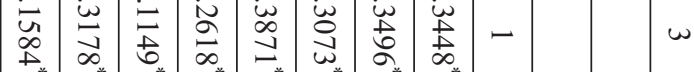

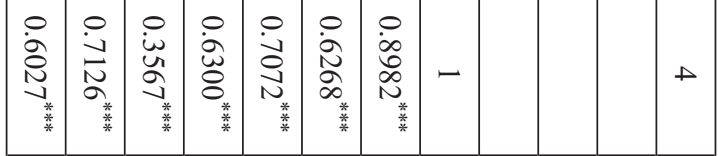

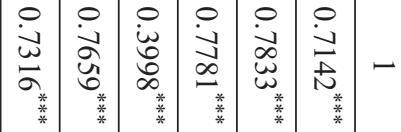

官

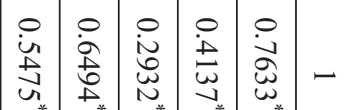

官

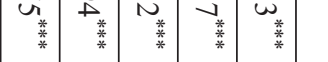

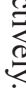

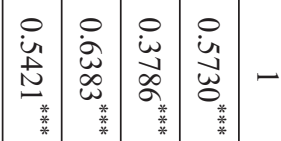

$\sigma$

$\Xi$

$\vec{\nabla}$

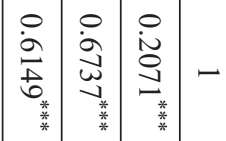

莺.

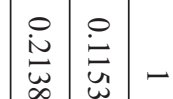

옹

8
8
8
8

莘章

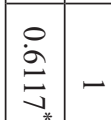

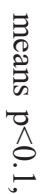

○

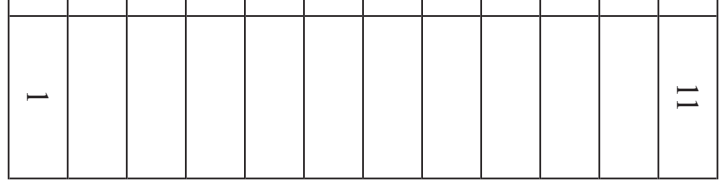


Li Fang, Zhang Sheng • Policy orientation, knowledge dynamic ability and green...

Zb. rad. Ekon. fak. Rij. • $2021 \cdot$ vol. $39 \cdot$ no. $1 \cdot 9-37$

\subsection{Empirical results}

Before regression analysis, the Hausman test of panel data is used to determine to select a fixed-effect model or random-effect model. The results show that the Hausman test of all models rejects the original hypothesis, as shown in Table 3. Therefore, the fixed-effect model is used for panel regression analysis.

Table 3: Results of the regression model of the mediating effect of knowledge dynamic ability

\begin{tabular}{|c|c|c|c|c|c|c|c|}
\hline Variable & Model 1-1 & Model 1-2 & Model 2 & Model 3 & Model 4 & Model 5-1 & Model 5-2 \\
\hline $\begin{array}{l}\text { Dependent } \\
\text { Variable }\end{array}$ & Process & Product & Find & $A c q u$ & Comb & Process & Product \\
\hline Env & $\begin{array}{l}1.893^{* * *} \\
(0.704)\end{array}$ & $\begin{array}{l}-0.295 \\
(0.527)\end{array}$ & $\begin{array}{l}1.733^{* * *} \\
(0.412)\end{array}$ & $\begin{array}{c}3.762^{* * *} \\
(1.103)\end{array}$ & $\begin{array}{l}-0.656 \\
(1.775)\end{array}$ & $\begin{array}{l}1.310^{*} \\
(0.692)\end{array}$ & $\begin{array}{c}-1.034^{* *} \\
(0.485)\end{array}$ \\
\hline Gov & $\begin{array}{c}0.227^{* * *} \\
(0.044)\end{array}$ & $\begin{array}{c}0.252^{* * *} \\
(0.033)\end{array}$ & $\begin{array}{c}0.231^{* * *} \\
(0.026)\end{array}$ & $\begin{array}{l}0.136^{* *} \\
(0.070)\end{array}$ & $\begin{array}{c}0.348^{* * *} \\
(0.112)\end{array}$ & $\begin{array}{c}0.197^{* * *} \\
(0.046)\end{array}$ & $\begin{array}{c}0.112^{* * *} \\
(0.032)\end{array}$ \\
\hline Prod & & & & & & $\begin{array}{l}-0.027 \\
(0.078)\end{array}$ & $\begin{array}{c}0.504^{* * *} \\
(0.054)\end{array}$ \\
\hline Acqu & & & & & & $\begin{array}{c}0.174^{* * *} \\
(0.031)\end{array}$ & $\begin{array}{l}-0.022 \\
(0.022)\end{array}$ \\
\hline Inte & & & & & & $\begin{array}{l}0.036^{* *} \\
(0.018)\end{array}$ & $\begin{array}{c}0.076^{* * *} \\
(0.013)\end{array}$ \\
\hline$p G D P$ & $\begin{array}{c}0.308^{* * *} \\
(0.088)\end{array}$ & $\begin{array}{c}1.408^{* * *} \\
(0.066)\end{array}$ & $\begin{array}{c}1.359^{* * * *} \\
(0.051)\end{array}$ & $\begin{array}{c}0.118 \\
(0.138) \\
\end{array}$ & $\begin{array}{c}0.800^{* * * *} \\
(0.222)\end{array}$ & $\begin{array}{l}0.295^{* *} \\
(0.136)\end{array}$ & $\begin{array}{c}0.665^{\text {**** }} \\
(0.095)\end{array}$ \\
\hline Indu & $\begin{array}{c}0.033^{* * *} \\
(0.006)\end{array}$ & $\begin{array}{c}0.002 \\
(0.004) \\
\end{array}$ & $\begin{array}{l}-0.002 \\
(0.003) \\
\end{array}$ & $\begin{array}{c}0.013 \\
(0.009) \\
\end{array}$ & $\begin{array}{c}0.051^{* * *} \\
(0.015)\end{array}$ & $\begin{array}{c}0.029^{* * * *} \\
(0.006)\end{array}$ & $\begin{array}{l}-0.001 \\
(0.004)\end{array}$ \\
\hline Mar & $\begin{array}{c}-0.036 \\
(0.034)\end{array}$ & $\begin{array}{c}-0.076^{* * *} \\
(0.025)\end{array}$ & $\begin{array}{c}-0.070^{* * *} \\
(0.020)\end{array}$ & $\begin{array}{c}0.015 \\
(0.053)\end{array}$ & $\begin{array}{c}-0.001 \\
(0.085)\end{array}$ & $\begin{array}{l}-0.040 \\
(0.032)\end{array}$ & $\begin{array}{l}-0.040^{*} \\
(0.023)\end{array}$ \\
\hline Open & $\begin{array}{c}-0.015^{* *} \\
(0.007)\end{array}$ & $\begin{array}{c}0.018^{* * *} \\
(0.005)\end{array}$ & $\begin{array}{c}0.021^{* * *} \\
(0.004)\end{array}$ & $\begin{array}{l}-0.012 \\
(0.011)\end{array}$ & $\begin{array}{l}-0.018 \\
(0.018)\end{array}$ & $\begin{array}{l}-0.011 \\
(0.007)\end{array}$ & $\begin{array}{l}0.009^{*} \\
(0.005)\end{array}$ \\
\hline Constant & $\begin{array}{c}6.854^{* * *} \\
(0.413) \\
\end{array}$ & $\begin{array}{c}-2.993^{* * *} \\
(0.309)\end{array}$ & $\begin{array}{c}-2.218^{* * *} \\
(0.241)\end{array}$ & $\begin{array}{c}7.948^{* * *} \\
(0.646) \\
\end{array}$ & $\begin{array}{c}-4.642^{* * *} \\
(1.040) \\
\end{array}$ & $\begin{array}{c}5.582^{* * *} \\
(0.525) \\
\end{array}$ & $\begin{array}{c}-1.344^{* * * *} \\
(0.367) \\
\end{array}$ \\
\hline Sample Size & 480 & 480 & 480 & 480 & 480 & 480 & 480 \\
\hline F Statistic & 32.67 & 42.71 & 48.41 & 23.79 & 8.75 & 15.34 & 9.78 \\
\hline P Value & 0.0000 & 0.0000 & 0.0000 & 0.0000 & 0.0000 & 0.0000 & 0.0000 \\
\hline R Square & 0.488 & 0.756 & 0.747 & 0.231 & 0.512 & 0.675 & 0.930 \\
\hline $\begin{array}{l}\text { Hausman Test } \\
\text { Statistic }\end{array}$ & $66.86^{* * *}$ & $60.48^{* * *}$ & $96.51^{* * *}$ & $109.34^{* * *}$ & $35.72^{* * *}$ & $40.59^{* * *}$ & $44.63^{* * *}$ \\
\hline $\begin{array}{l}\text { Regression } \\
\text { Model }\end{array}$ & $\begin{array}{l}\text { Fixed } \\
\text { Effect }\end{array}$ & $\begin{array}{l}\text { Fixed } \\
\text { Effect }\end{array}$ & $\begin{array}{l}\text { Fixed } \\
\text { Effect }\end{array}$ & $\begin{array}{l}\text { Fixed } \\
\text { Effect }\end{array}$ & $\begin{array}{l}\text { Fixed } \\
\text { Effect }\end{array}$ & $\begin{array}{l}\text { Fixed } \\
\text { Effect }\end{array}$ & $\begin{array}{l}\text { Fixed } \\
\text { Effect }\end{array}$ \\
\hline
\end{tabular}

Note: Significance test: * means $\mathrm{p}<0.1, * *$ means $\mathrm{p}<0.05, * * *$ means $\mathrm{p}<0.01$.

Source: Authors' calculation 
The step-by-step method is intended to examine the mediating effect of knowledge dynamic ability. The results of regression analysis were shown in Table 3. Model 1-1 and 1-2 are policy orientation impact analysis on green process innovation and green product innovation, model 2, 3, and 4 are policy orientation impact on knowledge dynamic ability, model 5-1 and 5-2 are policy orientation and knowledge dynamic ability impact on green process innovation and green product innovation.

Model 1-1 and model 1-2 respectively test the impact of environmental supervision and government subsidy on green process innovation and green product innovation. The results of model 1-1 show that environmental supervision and government subsidy have significant positive effects on green process innovation, with influence coefficients of 1.893 and 0.227 , respectively. Model 1-2 shows that environmental supervision has a negative but non-significant impact on green product innovation. Government subsidy has a significant positive impact on green product innovation, and the impact coefficient is 0.252 .

Model 2, 3, and 4 test the effects of policy orientation on knowledge production ability, knowledge acquisition ability and knowledge integration ability, respectively. The results of model 2 show that environmental supervision and government subsidy have significant positive effects on knowledge production ability, with influence coefficients of 1.733 and 0.231 , respectively. The results of model 3 show that environmental supervision and government subsidy have significant positive effects on knowledge acquisition ability, and the influence coefficients are 3.762 and 0.136 , respectively. The results of model 4 show that environmental supervision has a negative and non-significant impact on knowledge integration ability, and government subsidy positively and significantly correlates with knowledge integration ability, and the impact coefficient is 0.348 .

Models 5-1 and 5-2 simultaneously test the impact of policy orientation and knowledge dynamic ability on green innovation.

The results of model 5-1 show that environmental supervision is positively correlated with green process innovation, but only significantly at the level of $1 \%$, while government subsidy is positively and significantly correlated with green process innovation, with an impact coefficient of 0.197. Knowledge acquisition ability and knowledge integration ability are both positively and significantly correlated with green process innovation, with the influence coefficients of 0.174 and 0.036 , respectively. Knowledge production ability has no significant impact on green process innovation.

The results of model 5-2 show that environmental supervision is negatively and significantly correlated with green product innovation, with an impact coefficient of -1.034 , and government subsidy is positively correlated with green product innovation, with an impact coefficient of 0.112 . Knowledge production ability and knowledge integration ability are both positively and significantly correlated 
with green product innovation, with the influence coefficients of 0.504 and 0.074 , respectively. Knowledge acquisition ability has no significant impact on green product innovation.

\section{Results and discussion}

This paper empirically examines the mediating role of knowledge dynamic ability in the relationship between policy orientation and green innovation, and indicates the inducing mechanism of policy orientation. The results show that knowledge dynamic ability plays a complete mediating role in the relationship between environmental supervision and green innovations play a significant part in mediating the relationship between government funding and green innovation.

\subsection{Impact of Policy Orientation on Green Innovation}

(1) Environmental supervision is positively and significantly correlated with green process innovation and is negatively correlated with green product innovation, but not significant. It shows that environmental supervision has obvious inductive influence on green process innovation, but has potential inhibition influence on green product innovation. Under the supervision of government environmental department, enterprises adopt more technological innovations to realize the goal of environmentally friendly and green development. However, environmental supervision increases the operating expenses of enterprises, even squeezes the financial arrangements of enterprises in product innovation, resulting in negative correlation between environmental supervision and green product innovation. Therefore, in order to handle the supervision of local government's environmental department, enterprises choose more ways of process innovation to reduce the resource consumption of manufacturing technique and environmental pollution of production and processing links, while ignoring or strategically abandoning the way of green product innovation.

From the perspective of strategic choice, enterprises are facing more and more stringent environmental supervision in the daily operation process. The increasing policy pressure and environmental protection standards mean that enterprises must alleviate or eliminate the pressure of environmental supervision through green technology innovation. However, on account of the limited capital and technology resources of enterprises, it makes hard to put green process innovation and green product innovation into effect at the same time, so enterprises are facing the strategic choice of innovation strategy. Compared with process innovation, product innovation faces not only the uncertainty of technological innovation, but also the uncertainty of market. If enterprises choose green product innovation, they will face higher risks. Moreover, the existing environmental supervision attaches 
importance to the pollution control of manufacturing technique and technological process, and guides enterprises to choose technological renovation and upgrading for green technological innovation. Therefore, when choosing innovation strategy, enterprises will take green process innovation seriously and ignore the innovation of green products.

At the same time, in the case of limited resources, after choosing green process innovation as innovation strategy, enterprises invest more personnel and funds in green process innovation, crowding out the resources for the innovation of green products, resulting in environmental supervision promoting green process innovation and inhibiting green product innovation.

(2) Government subsidy is positively and significantly correlated with green process innovation and green product innovation, indicating that government subsidy has a powerful inductive effect on green innovation. The effect of government subsidy is greater than that of crowding out, which shows the effectiveness of government governance of technology market. Whether or not the government subsidy squeezes out some enterprises' investment, R\&D funding objectively increases the level of enterprise innovation funds, compensates for the loss of enterprise innovation caused by technology spillover, improves enterprise innovation incentives, and promotes enterprise green innovation activities and output.

This promotion role is comprehensive, which is the same for green process or product innovation. Government subsidy can help enterprises break through the constraints of limited resources to a certain degree, disperse the potential risks of green innovation, and ensure that enterprises have sufficient funds for green process and product innovation activities. Moreover, government R\&D investment can improve enterprise green innovation by creating and upgrading enterprise technology and equipment, training and introducing high-level technologically innovative talents, reducing fixed R\&D cost and manpower cost.

\subsection{Impact of Policy Orientation on Knowledge Dynamic Ability}

(1) Environmental supervision is positively and significantly correlated with knowledge production ability and knowledge acquisition ability, but has no significant impact on knowledge integration ability.

Environmental supervision requires enterprises to carry out environmental governance, which adds additional operating costs to enterprises. For the sake of it making up for the cost of environmental governance, enterprises will choose green technology innovation strategy to cut down resource consumption and pollutant emission. Under the pressure of environmental governance cost, in order to achieve green innovation, enterprises will choose two strategies: independent $R \& D$ innovation and external innovation. Enterprises' independent innovation requires them to enlarge 
their own R\&D input in green innovation, enhance their R\&D capability of green technology knowledge and enhance their knowledge production ability. Introducing external innovation requires enterprises to increase investment in technology import funds, purchase green innovation that meets the technological needs of enterprises at home and abroad through technology market, and improve knowledge acquisition ability. Therefore, environmental supervision promotes the improvement of knowledge production ability and knowledge acquisition capacity of enterprises.

The effect of environmental supervision on knowledge integration ability is not significant, which indicates that environmental supervision promotes the innovation ability of enterprises and does not affect the integration and digestion of technology. Enterprises absorb and utilize green innovation through technology integration, and then promote the level of green innovation. However, knowledge integration ability is mainly affected by technological factors, such as technological knowledge stock, R\&D investment, learning mechanism, organizational climate, etc. The impact of non-technological policy environment on knowledge integration ability is not significant.

(2) Government subsidy is positively and significantly correlated with knowledge production ability, knowledge acquisition ability and knowledge integration ability, indicating that government subsidy has a significant induced effect, which comprehensively improves the knowledge dynamic ability of enterprises.

Government subsidies compensate for the potential loss of innovation income caused by technology spillovers and improve the enthusiasm of enterprises to go in for R\&D activities. At the same time, the government subsidies will increase the social capital's expectation on the success probability of enterprise innovation and the quality of achievements, and improve the possibility of external financing of enterprises, and then promote enterprises to engage in R\&D activities and improve their knowledge production ability. The government subsidy enriches the technological capital of enterprises, enhances the negotiating power and purchasing power of enterprises in the technological market, and improves the knowledge acquisition ability of enterprises. Government subsidy directly promotes the overall $R \& D$ efforts of enterprises, promotes the technological innovation activities and reserves of enterprises, improves the ability of enterprises to absorb and absorb technology, and improves the ability of enterprises to integrate knowledge.

\subsection{Mediating Effect of Knowledge Dynamic Ability}

The regression results show that knowledge dynamic ability has a mediating effect between policy orientation and green innovation.

The results of model 5-1 show that environmental supervision is significantly related to green process innovation. The influence of government subsidy on green process 
innovation is remarkable and positive. Knowledge acquisition ability and knowledge integration ability are positively related to green process innovation. By comparing the results of models 1-1 and 5-1, we could find that the regression coefficient of environmental supervision is $1.893>1.310$, the regression coefficient of government subsidy is $0.227>0.197$, and the regression coefficient of policy orientation is reduced. $\mathrm{R}$-square of model is $0.488<0.675$. The degree of model-fitting has been improved significantly, which indicates that knowledge dynamic ability has a mediating effect between policy orientation and green process innovation.

Correspondingly, the results of model 5-2 show that environmental supervision is negatively and significantly correlated with green product innovation, and government subsidy is positively and significantly related to green product innovation. Knowledge production ability and knowledge integration ability are positively related to green product innovation. Comparing the results of model 1-2 and model 5-2, we find that the regression coefficient of environmental supervision is $-0.295>-1.034$, the regression coefficient of government subsidy is $0.252>0.112$, and the regression coefficient of policy orientation is reduced. R-square of the model is $0.756<0.930$. The degree of model-fitting has been significantly improved, which indicates that knowledge dynamic ability has a mediating effect between policy orientation and green product innovation.

(1) The mediating effect of knowledge dynamic ability on environmental supervision and green innovation

The mediating role of knowledge dynamic ability between $n$ environmental supervision and green innovation is shown in Figure 2.

Figure 2: The mediating role of knowledge dynamic ability in the relationship between environmental supervision and green innovation

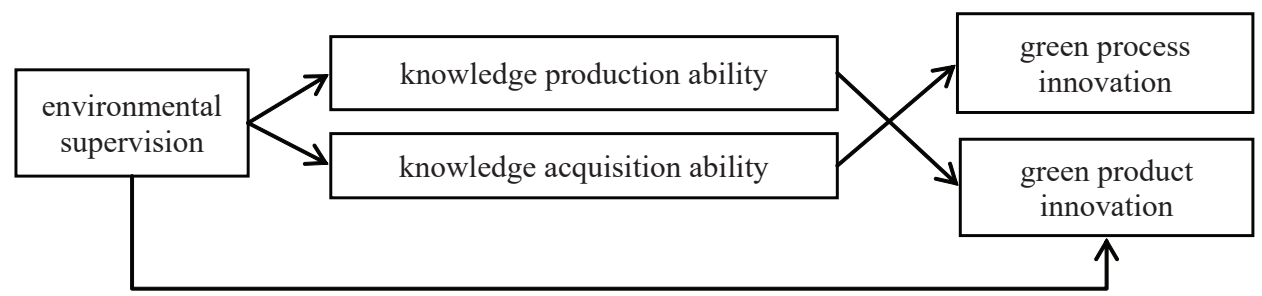

Source: Authors' summary based on the above empirical results

According to the results of model 1-1, 3 and 5-1, knowledge acquisition ability has a significant complete mediating effect between environmental supervision and green process innovation. Environmental supervision has a remarkable positive overall effect on green process innovation, but after introducing knowledge dynamic ability, 
the influence of knowledge acquisition ability is significant, and the direct effect of environmental supervision is no longer remarkable. It shows that the promotion of environmental supervision on green process innovation is mainly embodied by improving knowledge acquisition ability.

According to the results of model 1-2, 2 and 5-2, knowledge production ability has a significant mediating effect between environmental supervision and green product innovation. Environmental supervision has a remarkable and inhibitory impact on green product innovation directly. Different from the conclusion of Guo et al. (2018), due to the mediating role of knowledge production capacity, environmental supervision plays a remarkable role in promoting green product innovation indirectly. Direct negative impact and indirect positive impact coexist, which lead to the overall influence of environmental supervision on green product innovation is not remarkable. This means that in the study of the relationship between environmental supervision and green product innovation, it is of great theoretical value and practical significance to distinguish the direct effect and indirect effect and explore the guiding mechanism of environmental supervision on green innovation.

From Figure 2, we can see that environmental supervision induces green innovation. Environmental supervision improves green process innovation by enhancing enterprise knowledge acquisition ability and green product innovation by enhancing enterprise knowledge production ability. Environmental supervision will directly inhibit green product innovation, which will offset the indirect effect.

(2) The mediating effect of knowledge dynamic ability on government subsidy and green innovation

The mediating role of knowledge dynamic ability in the relationship between government subsidy and green innovation is shown in Figure 3.

Figure 3: The mediating role of knowledge dynamic ability in the relationship between government subsidy and green innovation

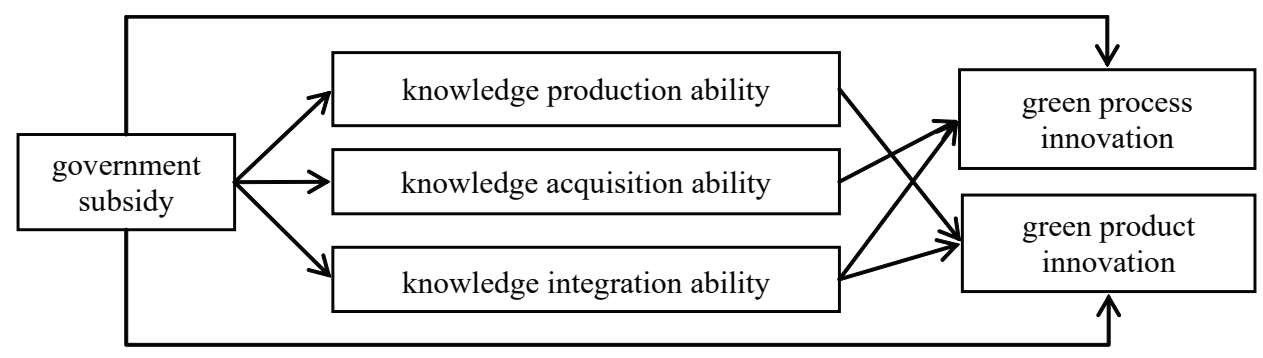

Source: Authors' summary based on the above empirical results 
According to the results of model 1-1, 3, 4 and 5-1, knowledge acquisition ability and knowledge integration ability play a significant part in mediating the relationship between government subsidy and green process innovation. Government subsidy plays a remarkable role in promoting green process innovation directly, and also has an indirect promoting impact on green process innovation through knowledge acquisition ability and knowledge integration ability.

According to the results of model 1-2,2, 4 and 5-2, knowledge production ability and knowledge integration ability have significant partial mediating effect on government subsidy and green product innovation. Government subsidy plays a remarkable role in promoting green product innovation directly, and also has an indirect promoting impact on green product innovation through knowledge production ability and knowledge integration ability.

According to Figure 3, government subsidy induces green innovation: government subsidy can promote green process innovation and green product innovation directly. At the same time, it will improve enterprise green process innovation by improving enterprise knowledge acquisition ability and knowledge integration ability, and green product innovation by improving enterprise knowledge production ability and knowledge integration ability.

\section{Conclusions}

By introducing knowledge dynamic ability into the framework of enterprise green innovation, and by analyzing the intermediary role of knowledge dynamic ability, this paper studies the induction mechanism of two policy orientations of environmental supervision and government subsidy on green innovation. Based on 480 data samples from 30 provinces in China in the period of 2000-2015, using the panel fixed effect regression model, the empirical tests show that knowledge dynamic ability has a remarkable mediating effect between policy orientation and green innovation. The specific results are as follows:

Firstly, knowledge acquisition ability has a remarkable and complete mediating effect between environmental supervision and green process innovation, and knowledge production ability has a remarkable mediating effect between environmental supervision and green product innovation. In particular, environmental supervision has concurrently direct inhibition and indirect promotion on green product innovation, resulting in no significant overall effect.

Secondly, knowledge acquisition ability and knowledge integration ability have a remarkable and complete mediating effect between government subsidy and green process innovation. Knowledge production ability and knowledge integration 
ability have a remarkable and complete mediating effect between government subsidy and green product innovation.

The incentive mechanisms of these two policy tools, environmental supervision and government subsidy, effect on green process innovation and green product innovation, can be concluded as follows:

Firstly, environmental supervision improves enterprise green process innovation by enhancing knowledge acquisition ability. Environmental supervision has a direct inhibition of green product innovation. It also promotes green product innovation by enhancing knowledge production ability. The direct inhibitory effect is offset by the indirect promoting effect.

Secondly, government subsidy has a direct promoting impact on the green process and product innovation. It also improves enterprise green process innovation by enhancing knowledge acquisition ability and knowledge integration ability and promotes enterprise green product innovation by enhancing knowledge production ability and knowledge integration ability.

The above conclusions indicate that the knowledge dynamic ability of enterprise is a core mechanism for government policy to guide green innovation. Therefore, under the supervision of government environmental department or with the support of the government subsidy, enterprises should attach importance to the cultivation of knowledge dynamic ability. Through improving knowledge production ability, knowledge acquisition ability, and knowledge integration ability, green innovation can be effectively promoted.

This paper finds out the policy-oriented inducing mechanism of knowledge dynamic ability and has a clearer understanding of the relationship between environmental supervision, government subsidy, and green innovation. However, this study also has several limitations, which should be solved in future research. First, based on the statistical data sample at the regional level, this paper only puts full attention to the mediating effect of knowledge dynamic ability. Future research can use enterprise-level statistical data and survey data to explore more incentive mechanisms at the micro-level. Second, the data sample only includes provincial data in China, which means the conclusions may be peculiar and suitable to China or developing countries and regions. Replications of this study in other countries are necessary, and future studies would further discuss the universality of these conclusions. Third, this study examines the mediating role of knowledge dynamic ability, while moderating effects are not a consideration in the model. the mediating effect of knowledge dynamic ability may be moderated by factors of institutional context and enterprise characteristics, such as policy stability and enterprise ownership type. Future research can examine these moderating effects by establishing a moderated mediation model. 


\section{References}

Ambec, S., Barla, P. (2002) "A theoretical foundation of the Porter hypothesis", Economics Letters, Vol. 75, No. 3, pp. 355-360, doi: 10.1016/s01651765(02)00005-8.

Antonioli, D., Marzucchi, A., Montresor, S. (2014) "Regional Innovation Policy and Innovative Behaviour: Looking for Additional Effects", European Planning Studies, Vol. 22, No. 1, pp. 64-83, doi: 10.1080/09654313.2012.722977.

Baron, R., Kenny, D. (1986) "The moderator-mediator variable distinction in social psychological research: conceptual, strategic, and statistical considerations", Journal of Personality and Social Psychology, Vol. 51, No. 6, pp. 1173-1182, doi: 10.1037/0022-3514.51.6.1173.

Barrales-Molina, V., Benitez-Amado, J., Perez-Arostegui N. M. (2010) "Managerial perceptions of the competitive environment and dynamic capabilities generation", Industrial Management and Data Systems, Vol. 110, No. 9, pp. 1355-1384, doi: 10.1108/02635571011087437.

Boer, M.D., Bosch, F.A.J.V., Volberda, H.W. (1999) "Managing Organizational Knowledge Integration in the Emerging Multimedia Complex", Journal of Management Studies, Vol. 36, No. 3, pp. 379-398, doi: 10.1111/1467-6486.00141.

Bronzini, R., Piselli, P. (2016) "The impact of R\&D subsidies on firm innovation", Research Policy, Vol. 45, No. 2, pp. 442-457, doi: 10.1016/j.respol.2015.10.008.

Buisseret, T. J., Cameron, H. M., Georghiou, L. (1995) "What difference does it make? Additionality in the public support of R\&D in large firms", International Journal of Technology Management, Vol. 10, No. 4-5, pp. 587-600.

Cassiman, B., Veugelers, R. (2006) "In Search of Complementarity in Innovation Strategy: Internal R\&D and External Knowledge Acquisition", Management Science, Vol. 52, No. 1, pp. 68-82, doi: 10.1287/mnsc.1050.0470.

Chaminade, C., Vang, J. (2008) "Globalisation of knowledge production and regional innovation policy: Supporting specialized hubs in the Bangalore software industry", Research Policy, Vol. 37, No. 10, pp. 1684-1696, doi: 10.1016/j.respol.2008.08.014.

Chen, J., Cheng, J., Sheng, D. (2017) "Regional eco-innovation in China: An analysis of eco-innovation levels and influencing factors", Journal of Cleaner Production, No. 153, pp. 1-14, doi: 10.1016/j.jclepro.2017.03.141.

Chen, Y. S., Lai, S. B., Wen, C. T. (2006) "The Influence of Green Innovation Performance on Corporate Advantage in Taiwan", Journal of Business Ethics, Vol. 67, No. 4, pp. 331-339, doi: 10.1007/s10551-006-9025-5.

Chen, Y., Chang, C. (2013) "The Determinants of Green Product Development Performance: Green Dynamic Capabilities, Green Transformational Leadership, and Green Creativity", Journal of Business Ethics, Vol. 116, No. 1, pp. 107-119, doi: 10.1007/s10551-012-1452-x. 
Cheng, C. C. J., Yang, C., Sheu, C. (2016) "Effects of open innovation and knowledge-based dynamic capabilities on radical innovation: An empirical study", Journal of Engineering \& Technology Management, No. 41, pp. 79-91, doi: 10.1016/j. jengtecman.2016.07.002.

Chintrakarn, P. (2008) "Environmental regulation and U.S. states' technical inefficiency", Economics Letters, Vol. 100, No. 3, pp. 363-365, doi: 10.1016/j. econlet.2008.02.030.

Clarysse, B., Wright, M., Mustar, P. (2009) "Behavioral additionality of R\&D subsidies: A learning perspective", Research Policy, Vol. 38, No. 10, pp. 1517 1533, doi: 10.1016/j.respol.2009.09.003.

Czarnitzki, C., Lopesbento, C. (2014) "Innovation Subsidies: Does the Funding Source Matter for Innovation Intensity and Performance? Empirical Evidence from Germany", Industry \& Innovation, Vol. 21, No. 5, pp. 380-409, doi: 10.1080/13662716.2014.973246.

Czarnitzki, D., Etro, F., Kraft, K. (2014) "Endogenous Market Structures and Innovation by Leaders: An Empirical Test", Economica, Vol. 81, No. 321, pp. 117-139, doi: 10.1111/ecca.12061.

Dangelico, R. M., Pujari, D., Pontrandolfo, P. (2017) "Green Product Innovation in Manufacturing Firms: A Sustainability-Oriented Dynamic Capability Perspective", Business Strategy and the Environment, Vol. 26, No. 4, pp. 490506, doi: 10.1002/bse.1932.

David, P. A., Hall, B. H., Toole, A. A. (2000) "Is public R\&D a complement or substitute for private $\mathrm{R} \& \mathrm{D}$ ? A review of the econometric evidence", Research Policy, Vol. 29, No. 4-5, pp. 497-529, doi: 10.1016/s0048-7333(99)00087-6.

Deeds, D. L., Decarolis, D., Coombs, J. (2000) "Dynamic capabilities and new product development in high technology ventures: An empirical analysis of new biotechnology firms", Journal of Business Venturing, Vol. 15, No. 3, pp. 211229, doi: 10.1016/s0883-9026(98)00013-5.

Delmas, M. A. (2002) "Innovating against European rigidities: Institutional environment and dynamic capabilities", Journal of High Technology Management Research, Vol. 13, No. 1, pp. 19-43, doi: 10.1016/s10478310(01)00047-5.

Ellonen, H., Wikström, P., Jantunen, A. (2009) "Linking dynamic-capability portfolios and innovation outcomes", Technovation, Vol. 29, No. 11, pp. 753762, doi: 10.1016/j.technovation.2009.04.005.

Feng, Z., Chen, W. (2018) "Environmental Regulation, Green Innovation, and Industrial Green Development: An Empirical Analysis Based on the Spatial Durbin Model”, Sustainability, Vol. 10, No. 1, p. 223, doi: 10.3390/su10010223.

Guo, D., Guo, Y., Jiang, K. (2016) "Government-subsidized R\&D and firm innovation: Evidence from China", Research Policy, Vol. 45, No. 6, pp. 1129 1144, doi: 10.1016/j.respol.2016.03.002. 
Guo, Y. et al. (2018) "Environmental Regulation, Government R\&D Funding and Green Technology Innovation: Evidence from China Provincial Data", Sustainability, Vol. 10, No. 4, p. 940, doi: 10.3390/su10040940.

Görg, H., Strobl, E. (2007) "The Effect of R\&D Subsidies on Private R\&D", Economica, Vol. 74, No. 294, pp. 215-234, doi: 10.1111/j.1468-0335.2006.00547.x.

Hamamoto, M. (2006) "Environmental regulation and the productivity of Japanese manufacturing industries", Resource \& Energy Economics, Vol. 28, No. 4, pp. 299-312, doi: 10.1016/j.reseneeco.2005.11.001.

Hong, J., Zhang, Y., Ding, M. (2018) "Sustainable supply chain management practices, supply chain dynamic capabilities, and enterprise performance", Journal of Cleaner Production, No. 172, pp. 3508-3519, doi: 10.1016/j. jclepro.2017.06.093.

King, A. A., Tucci, C. L. (2002) "Incumbent Entry into New Market Niches: The Role of Experience and Managerial Choice in the Creation of Dynamic Capabilities", Management Science, Vol. 48, No. 2, pp. 171-186, doi: 10.1287/ mnsc.48.2.171.253.

Lanoie, P., Patry, M., Lajeunesse, R. (2008) "Environmental regulation and productivity: testing the porter hypothesis", Journal of Productivity Analysis, Vol. 30, No. 2, pp. 121-128, doi: 10.1007/s11123-008-0108-4.

Lanoie, P. et al. (2011) "Environmental Policy, Innovation and Performance: New Insights on the Porter Hypothesis", Journal of Economics \& Management Strategy, Vol. 20, No. 3, pp. 803-842, doi: 10.1111/j.1530-9134.2011.00301.x.

Leeuwen, G. V., Mohnen, P. (2017) "Revisiting the porter hypothesis: an empirical analysis of green innovation for the Netherlands", Economics of Innovation \& New Technology, Vol. 26, No. 1-2, pp. 63-77, doi: 10.1080/10438599.2016.1202521.

Lin, H. et al. (2014) "Can political capital drive corporate green innovation? Lessons from China", Journal of Cleaner Production, Vol. 64, No. 2, pp. 6372, doi: 10.1016/j.jclepro.2013.07.046.

Monferrer, D., Blesa, A., Ripollés, M. (2015) "Born globals trough knowledgebased dynamic capabilities and network market orientation", Business Research Quarterly, Vol. 18, No. 1, pp. 18-36, doi: 10.1016/j.brq.2014.04.001.

Montero, J. (2002) "Market Structure and Environmental Innovation", Journal of Applied Economics, Vol. 5, No. 2, pp. 293-325, doi: 10.1080/15140326. 2002.12040581.

Perino, G., Requate, T. (2012) "Does more stringent environmental regulation induce or reduce technology adoption? When the rate of technology adoption is inverted U-shaped", Journal of Environmental Economics \& Management, Vol. 64, No. 3, pp. 456-467, doi: 10.1016/j.jeem.2012.03.001.

Peuckert, J. (2014) "What shapes the impact of environmental regulation on competitiveness? Evidence from Executive Opinion Surveys", Environmental 
Innovation and Societal Transitions, No. 10, pp. 77-94, doi: 10.1016/j. eist.2013.09. 009.

Porter, E. M., van der Linde, C. (1995) "Toward A New Conception of the Environment-Competitiveness Relationship", Journal of Economic Perspectives, Vol. 9, No. 4, pp. 97-118, doi: 10.1257/jep.9.4.97.

Rexhäuser, S., Rammer, C. (2014) "Environmental Innovations and Firm Profitability: Unmasking the Porter Hypothesis", Environmental \& Resource Economics, Vol. 26, No. 1, pp. 145-167, doi: 10.1007/s10640-013-9671-x.

Rubashkina, Y., Galeotti, M., Verdolini, E. (2015) "Environmental regulation and competitiveness: Empirical evidence on the Porter Hypothesis from European manufacturing sectors", Energy Policy, Vol. 83, No. 35, pp. 288-300, doi: 10.1016/j.enpol.2015.02.014.

Russo, M. V. (2010) "Explaining the Impact of ISO 14001 on Emission Performance: A Dynamic Capabilities Perspective on Process and Learning", Business Strategy \& the Environment, Vol. 18, No. 5, pp. 307-319, doi: 10.1002/bse.587.

Salazar, Á. J., Peláez, E. (2012) "The organic growth of dynamic capabilities for innovation within resource constrained environments", International Journal of Technology Management \& Sustainable Development, Vol. 10, No. 3, pp. 231250, doi: 10.1386/tmsd.10.3.231_1.

Stucki, T. et al. (2018) "How different policy instruments affect green product innovation: A differentiated perspective", Energy Policy, No. 114, pp. 245-261, doi: 10.1016/j.enpol.2017.11.049.

Teece, D. J., Pisano, G., Shuen, A. (1997) "Dynamic capabilities and strategic management", Strategic Management Journal, Vol. 18, No. 7, pp. 509-533, doi: 10.1002/(sici)1097-0266(199708)18:7<509::aid-smj882>3.0.co;2-z.

Teece, D. J. (2010) "Explicating dynamic capabilities: the nature and microfoundations of (sustainable) enterprise performance", Strategic Management Journal, Vol. 28, No. 13, pp. 1319-1350, doi: 10.1002/smj.640.

Villegas-Palacio, C., Coria, J. (2010) "On the interaction between imperfect compliance and technology adoption: taxes versus tradable emissions permits", Journal of Regulatory Economics, Vol. 38, No. 3, pp. 274-291, doi: 10.1007/ s11149-010-9125-0.

Volchek, D., Jantunen, A., Saarenketo, S. (2013) “The institutional environment for international entrepreneurship in Russia: Reflections on growth decisions and performance in SMEs", Journal of International Entrepreneurship, Vol. 11, No. 4, pp. 320-350, doi: 10.1007/s10843-013-0115-z.

Wagner, M. (2007) "On the relationship between environmental management, environmental innovation and patenting: Evidence from German manufacturing firms", Research Policy, Vol. 36, No. 10, pp. 1587-1602, doi: 10.1016/j. respol.2007. 08.004. 
Walker, W. R. (2011) "Environmental Regulation and Labor Reallocation: Evidence from the Clean Air Act", American Economic Review, Vol. 101, No. 3, pp. 442447, doi: 10.1257/aer.101.3.442.

Wang, Y., Li, J., Furman, J. L. (2017) "Firm performance and state innovation funding: Evidence from China's innofund program", Research Policy, Vol. 46, No. 6, pp. 1142-1161, doi: 10.1016/j.respol.2017.05.001.

Weerawardena, J. et al. (2015) "The role of the market sub-system and the sociotechnical sub-system in innovation and firm performance: a dynamic capabilities approach", Journal of the Academy of Marketing Science, Vol. 43, No. 2, pp. 221-239, doi: 10.1007/s11747-014-0382-9.

Wong, S. K. S. (2012) "The influence of green product competitiveness on the success of green product innovation: Empirical evidence from the Chinese electrical and electronics industry", European Journal of Innovation Management, Vol. 15, No. 4, pp. 468-490, doi: 10.1108/14601061211272385.

Wong, S. K. S. (2013) "Environmental Requirements, Knowledge Sharing and Green Innovation: Empirical Evidence from the Electronics Industry in China", Business Strategy \& the Environment, Vol. 22, No. 5, pp. 321-338, doi: 10.1002/bse.1746.

$\mathrm{Wu}, \mathrm{K}$. et al. (2016) "Exploring eco-innovation in dynamic organizational capability under incomplete information in the Taiwanese lighting industry", International Journal of Production Economics, No. 181, pp. 419-440, doi: 10.1016/j. ijpe.2015.10.007.

Xie, X. et al. (2016) "Green Process Innovation and Financial Performance in Emerging Economies: Moderating Effects of Absorptive Capacity and Green Subsidies", IEEE Transactions on Engineering Management, Vol. 63, No. 1, pp. 1-12, doi: 10.1109/tem.2015.2507585.

Zhang, L. et al. (2019) "Does China's emissions trading system foster corporate green innovation? Evidence from regulating listed companies", Technology Analysis \& Strategic Management, Vol. 31, No. 2, pp. 199-212, doi: 10.1080/09537325.2018. 1493189.

Zhang, Y. et al. (2018) "Impact of environmental regulations on green technological innovative behavior: An empirical study in China", Journal of Cleaner Production, No. 188, pp. 763-773, doi: 10.1016/j.jclepro.2018.04.013.

Zhao, X., Sun, B. (2016) "The influence of Chinese environmental regulation on corporation innovation and competitiveness", Journal of Cleaner Production, Vol. 112, No. 4, pp. 1528-1536, doi: 10.1016/j.jclepro.2015.05.029.

Zheng, S., Wei, Z., Jian, D. (2011) "Knowledge-based dynamic capabilities and innovation in networked environments", Journal of Knowledge Management, Vol. 15, No. 6, pp. 1035-1051, doi: 10.1108/13673271111179352.

Zhu, P., Weimin, X.U., Lundin, N. (2006) “The impact of government's fundings and tax incentives on industrial R\&D investments-Empirical evidences from industrial sectors in Shanghai", China Economic Review, Vol. 17, No. 1, pp. 51-69, doi: 10.1016/j.chieco.2005.04.002. 
Zollo, M., Winter, S. G. (2002) "Deliberate Learning and the Evolution of Dynamic Capabilities", Organization Science, Vol. 13, No. 3, pp. 339-351, doi: 10.1287/ orsc. 13.3.339.2780.

\title{
Usmjerenost prema politici, dinamička sposobnost znanja i zelene inovacije: medijacijski model temeljen na panel podacima kineskog provincijskog odbora
}

\author{
Li Fang $^{1}$, Zhang Sheng ${ }^{2}$
}

\begin{abstract}
Sažetak
Nadzor okoliša $i$ vladine subvencije važni su alati vlade za promicanje zelenih inovacija. Utjecaj tih dviju smjernica politike na rast zelene inovacije se siri, ali potrebno je dodatno istražiti specifične neizravne mehanizme usmjerenosti politike koje potiču zelene inovacije. U ovom radu uvodi se dinamička sposobnost znanja (sposobnost proizvodnje znanja, sposobnost stjecanja znanja, sposobnost integracije znanja) $u$ okvir analize poduzeća zelenih inovacija i proučava posrednički učinak sposobnosti dinamike znanja na usmjerenost politike i zelene inovacije. Empirijski nalazi koji se temelje na panel podacima 30 kineskih provincija za razdoblje od 2000. do 2015. su slijedeći: Prvo, dinamička sposobnost znanja ima značajnu posredničku ulogu između promicanja usmjerenosti prema politici i zelenih inovacija, što ukazuje na to da je poboljšanje dinamičke sposobnosti znanja temeljni mehanizam usmjeravanja politike za poticanje zelenih inovacija u poduzeću. Drugo, dinamička sposobnost znanja igra potpunu posredničku ulogu u odnosu između nadzora okoliša i zelenih inovacija. Nadzor okoliša promiče inovacije zelenih procesa povećavajući sposobnost stjecanja znanja i potiče inovacije zelenih proizvoda poboljšanjem sposobnosti proizvodnje znanja. Treće, dinamička sposobnost znanja ima djelomično posredničku ulogu između državnih subvencija i zelenih inovacija. Državne subvencije poboljšavaju inovacije zelenog procesa u poduzeću povećavanjem sposobnosti stjecanja znanja i sposobnosti integracije znanja, te potiču inovacije zelenih proizvoda u poduzeću povećavanjem sposobnosti proizvodnje znanja $i$ sposobnosti integracije znanja.
\end{abstract}

Ključne riječi: usmjerenost na politiku, dinamička sposobnost znanja, zelene inovacije, nadzor zaštite okoliša, državna subvencija

JEL klasifikacija: Q55, Q58, O32, O38

1 Predavač, Nanjing University of Science and Technology, School of Intellectual Property, science technology policy and management, No. 200, Xiaolingwei Street, Nanjing, Jiangsu Province, Kina, 210094. Znanstveni interes: upravljanje inovacijama, pravo intelektualnog vlasništva, politika znanstvene tehnologije.Tel.: +8615829715128.E-mail: 532296776@qq.com.

2 Redoviti profesor, Xi'an Jiaotong University, School of Public Policy and Administration, science technology policy and management, NO. 28, Road Xianning West, Beilin District, Xi'an City, Shannxi Province, Kina. Znanstveni interes: politika znanstvene tehnologije, državno upravljanje 710049.Tel.: +8602982665254.E-mail:xjtuppasci@163.com. (Osoba za kontakt). 